\title{
Myten om det borgerlige demokrati
}

AF RUNE MØLLER STAHL

SLAGMARK \#72

SIDER: I65-I70

Søren Mau har med Hov stemmen! skrevet en letlæst og engagerende pamflet med et klart handlingsorienteret politisk sigte og lykkeligt befriet for traditionel jargon. Den er i sig selv et beundringsværdigt stykke formidlende polemik. Bogen formår dog aldrig helt at overbevise om sit hovedargument, nemlig at det parlamentariske demokrati primært er en ideologisk mekanisme for at opretholde den herskende kapitalistiske orden, og at det ikke at stemme er en væsentlig del af en effektiv strategi for social forandring.

Jeg vil gerne fokusere på det faktum, at dagens repræsentative demokrati ikke er designet som et røgslør for kapitalismen. Det er opstået som et produkt af en lang, konfliktfyldt politisk kamp. Når vi i moderne kapitalistiske samfund har parlamentarisk styre med almen valgret, er det fordi folkelige bevægelser igennem historien har vundet disse som politiske sejre, og ikke fordi det er en nødvendig mekanisme for reproduktionen af den kapitalistiske orden. Historien viser tværtimod, at kapitalismen sagtens kan fungere uden parlamentarisk demokrati. Der er meget, der tyder på, at vi i den nuværende neoliberale periode igen er ved at se stigende modsætninger mellem kapitalisme og demokrati. I en situation, hvor det repræsentative demokrati er truet, er der ikke brug for en kampagne for at delegitimere parlamenter og valg. Der er snarere brug for at forberede et forsvar for det parlamentariske demokrati og en kamp for at udvide dets rækkevidde. 


\section{'STEM IKKE' SOM STRATEGI}

Søren Maus argument i Hoev stemmen! har to hovedelementer. På den ene side indeholder bogen en analyse af udhulingen af de nationale parlamenters indflydelse i kraft af finansiel globalisering og politisk konsensus om neoliberal politik. På den anden side rummer bogen et argument for at stemmeafgivelse til nationale parlamenter i sig selv er politisk skadeligt, fordi det legitimerer den herskende institutionelle orden og dermed spærrer for opkomsten af politiske alternativer.

Det første element er relativt ukontroversielt på den akademiske venstrefløj, som Mau placerer sig indenfor. Analysen af demokratiets aktuelle tilstand lægger sig eksempelvis ret tæt op af det, som den engelske socialdemokratiske politilog Colin Crouchs kalder den post-demokratiske tilstand.

Det andet element, derimod, er langt mere substantielt, og det er også her, jeg vil koncentrere det meste af min analyse. Og da bogen bevidst er skrevet som et politisk kampskrift, vil jeg koncentrere mig om det politiske strategiske niveau.

Det umiddelbare problem her er, at bogen er fattig på strategi. Deltagelse i demokratiske valg og forsøget på at erobre parlamentarisk magt har været et helt centralt redskab for progressive bevægelser igennem historien. Derfor virker det overilet at opgive dette til fordel for en ret luftig opfordring til at "gøre noget".

Min hovedindvending mod bogens argument er dog imidlertid snarere, at Søren Mau med sin identifikation af det parlamentariske demokrati med den borgerlige orden forsimpler den konfliktfyldte historiske sammenhæng mellem kapitalisme og demokrati. Dermed risikerer man ikke bare at understøtte den vidt udbredte myte om et modsætningsforhold mellem radikal social forandring og institutionelt demokrati, men kan også med en manikæisk opdeling i sandt og falskt demokrati overse strategiske åbninger for reelle demokratiske fremskridt.

\section{REPRESENTATION SOM IDEOLOGISK ROGSLOR}

Mau opregner en række inspirationskilder på den teoretiske venstrefløj, herunder Hardt, Negri, Žižek og Rancière. Det eksplicitte fokus på parlamentsvalg som det strategiske hovedproblem deler Mau dog primært med Alain Badiou, der i Metapolitikken taler om "kapitalisme-parlamentarismen", og som i forordet til den italienske udgave eksplicit skriver, at "fjenden i dag er ikke Imperiet eller Kapitalismen. 
Fjenden er Demokratiet”. Denne udpegning af det parlamentariske demokrati som ikke bare et ideologisk blændværk, men også et helt centralt apparat i opretholdelsen af den kapitalistiske orden, synes at være styrende for Maus analyse og strategi.

Dette er imidlertid en tvivlsom læsning af det repræsentative demokratis historie. En læsning, som kan udgøre en alvorlig forhindring for at udvikle adækvate svar i en tid, hvor demokrati og kapitalisme i stigende grad bliver frakoblet hinanden, og hvor forsvaret for demokratisk suverænitet dermed kan blive en væsentlig politisk kamplads. Problemet for Mau og Badiou er, at en diagnose, der anfører, at demokrati i dagens Danmark allerede er fuldstændigt fraværende, giver relativt dårlige analytiske redskaber til at forstå og modgå den løbende afdemokatisering, der faktisk foregår. I natten bliver alle katte grå og alle regimer udemokratiske.

Samtidig betyder strategien med at afvise parlamentsvalg som ren ideologi, at man understøtter en udbredt ideologisk forestilling om, at der er noget essentielt borgerligt og liberalt ved repræsentative valghandlinger. Det gør det let at fremstille alternativer til liberaldemokratisk kapitalisme som enten luftige utopier eller totalitarisme.

Det repræsentative demokrati er imidlertid hverken den eneste eller den naturlige ramme for kapitalismen. Faktisk kan kapitalismen sagtens fungere uden almen stemmeret og repræsentative strukturer. Enten ved et oligarkisk system med indskrænket stemmeret, som i konstitutionelle monarkier (som Storbritannien efter The Glorious Revolution og Estrup-tidens Danmark), eller under diktaturer, som i 1980'ernes Latinamerika eller de fascistiske styrer i mellemkrigstiden, hvor den private ejendomsret og profitraten havde det strålende. Snarere end at være et designet røgslør for kapitalistisk orden er de repræsentative systemer med universel stemmeret, der karakteriserer det moderne Europa, opstået ved en lang politisk kamp.

\section{STEMMERETTENS KONFLIKTFYLDTE FREMVEKST}

Historisk har de europæiske eliter været ekstremt skeptiske overfor idéen om repræsentation og almen stemmeret ud fra antagelsen om, at det fattige flertal ville kunne bruge stemmeretten til at ekspropriere det formuende mindretal. 1800-tallets liberale, som i de fleste tilfælde lagde grundstenene til de moderne repræsentative systemer, var skeptiske overfor almen stemmeret, og selv mere progressive liberale stemmer som John Stuart Mill anbefalede kraftige begrænsninger af stem- 
meretten. Det var først gennem massivt pres fra folkelige bevægelser som arbejderbevægelsen og kvindebevægelsen, at den almene valgret blev presset igennem. Derfor var kravet om et reelt repræsentativt demokrati og suveræne parlamenter med frie hemmelige valg også en central del af den tidlige arbejderbevægelses krav. Da Marx og Engels i 1848 formulerede de konkrete krav fra Det tyske kommunistiske parti, omhandlede tre første krav etableringen af et tysk parlament med universel stemmeret og deltagelse af arbejdere.

Det var først i perioden efter Anden verdenskrig, at modsætningen mellem privat ejendom og demokrati begyndte at træde i baggrunden. Gennem idéen om liberalt demokrati blev kapitalisme ikke længere set som stående i modsætning til demokratiet, men i stedet som det eneste socioøkonomiske system, der kunne understøtte demokrati i det lange løb. Denne identifikation af demokrati og kapitalisme, ville bare en generation tidligere have virket absurd. Ikke desto mindre blev denne nye ideologiske konstruktion paradoksalt nok understøttet af venstrefløjen. På den kommunistiske side forstærkede man billedet af en kobling mellem kapitalisme og demokrati ved at forlade den traditionelle arbejderbevægelses forsvar for den demokratiske republik for i stedet at forsvare et autoritært system som Sovjetunionen. Og på den socialdemokratiske side accepterede man koblingen mellem kapitalisme og demokrati ved, at man accepterede det liberale diktum om, at valget stod mellem enten kapitalistisk demokrati eller totalitarisme, og at man derfor måtte opgive at demokratisere økonomien og slå sig til tåls med et demokrati, der stoppede ved fabriksporten.

Det institutionelle kompromis mellem kapitalisme og demokrati var imidlertid ikke gratis for kapitalen. Kombinationen af almen stemmeret, strejkevåbnet og folkelig mobilisering ledte til etableringen af et socialt sikkerhedsnet og markante forbedringer for den brede befolkning i midten af det 20. århundrede. Samtidigt viser Thomas Piketty og Emmanuel Saez' opgørelser, at perioden mellem 1945-70 var den historiske periode, hvor den rigeste ene procent har haft den historisk laveste andel af nationalindkomsten.

\section{KAPITALENS OG DEMOKRATIETS SKILSMISSE}

Man kan vælge at afvise disse tilkæmpede sociale og institutionelle fremskridt, herunder den almene valgret, som irrelevante, fordi de ikke ledte til en overskridelse af det kapitalistiske system og til et "i sandhed demokratisk samfund", 
som Søren Mau taler om. Men det faktum, at kapitalismen har tilpasset sig et nyt institutionelt terræn med nye styrkeforhold, betyder ikke, at disse institutioner kan reduceres til ideologiske apparater til at opretholde den herskende orden.

Derfor har den globale økonomiske elite heller ikke været ligeglad med det parlamentariske demokrati. Den undergravning af demokratiet til fordel for globale kapitalkræfter, som Mau rigtigt optegner i bogen, er ikke blot en naturlig følge af teknologisk udvikling. Det er et produkt af en lang politisk proces, som gennem de sidste år har drænet de valgte, repræsentative foras beslutningskraft. Fri global kapitalmobilitet har gjort regeringer sårbare overfor pres fra finansielle markeder, og institutionelle ændringer som uafhængige centralbanker og bindende frihandelsaftaler som TTIP har effektivt afpolitiseret store dele af den økonomiske politik. Den globale neoliberale bevægelse kan på mange måder ses som et forsøg på at begrænse den indflydelse, som valgte parlamenter har over samfundsøkonomien. Et forsøg, der er i stort omfang har været succesfuldt.

Men netop fordi det neoliberale forsøg på at begrænse demokratiet er politisk, er det ikke nødvendigvis irreversibelt. Udviklingen i Latinamerika i de seneste årtier har vist, at kombinationen af folkelig mobilisering og parlamentariske regeringer faktisk er i stand til at bryde den neoliberale udvikling og åbne op for øget social lighed og demokratisk deltagelse. Og opkomsten af partier som Syriza og Podemos i Europa tyder på at parlamentarisk politik kan tage en langt mere radikal drejning, end man har set i mange årtier.

Søren Mau taler for, at politiske strategier skal styres af en konkret analyse af den historiske situation. I den sammenhæng virker det for mig som om national parlamentarisk politik i disse år bliver en mere, ikke mindre central kampplads. Især hvis man sammenligner de nuværende sociale kampe i Sydeuropa og Latinamerika med tidligere forsøg på at omgå national politik, som alter-globaliseringsbevægelsen eller de sociale fora, der et årti efter har efterladt sig få blivende spor.

Hvis man ser på den bølge af protestbevægelser som inspireret af Tunesien og Egypten spredte sig over kloden i 2011, kan man også konstatere, at de har klaret sig bedst de steder, hvor de har fået et parlamentarisk udtryk, som for eksempel i Spanien eller Grækenland. De steder, hvor det ikke er lykkedes bevægelserne at koble sig til parlamentariske kræfter, som Tahrir-bevægelsen i Egypten eller Occupy Wall Street i USA, er de enten ebbet ud eller blevet knust. 
Den mest effektive strategi til at modgå den afkobling mellem kapitalisme og demokrati, som vi ser i disse år, er ikke at afvise formelle demokratiske institutioner og rettigheder som meningsløse ideologiske udtryk. Det er tværtimod at forberede et offensivt forsvar for det truede parlamentariske demokrati. Hvorfor? Fordi de nationale parlamentariske institutioner i samspil med social mobilisering er det bedste bud på et modspil mod den stigende magt til globale oligarkiske elite. Samtidig udgør det parlamentariske demokrati i dag, som det gjorde for Marx og Engels i 1800-tallet, en potentiel trædesten frem mod en mere gennemgribende demokratisering af økonomien og samfundslivet. 